\title{
Carfentrazone-ethyl and glyphosate drift inhibits uredinial formation of Austropuccinia psidii on Eucalyptus grandis leaves
}

\author{
Samuel Alves dos Santos, ${ }^{a}$ Leonardo David Tuffi-Santos, ${ }^{\text {b }}$ \\ Francisco André Ossamu Tanaka, ${ }^{c}$ Bruno Francisco Sant'Anna-Santos, ${ }^{\mathrm{d}}$ \\ Fabrício de Ávila Rodrigues ${ }^{\mathrm{a}}$ and Acelino Couto Alfenas ${ }^{\mathrm{a}}{ }^{*} \odot$
}

\begin{abstract}
BACKGROUND: The response to infection of Austropuccinia psidii in resistant (CLR-383) and susceptible (CLR-384) Eucalyptus grandis clones, exposed to herbicide drift of carfentrazone-ethyl, glyphosate and a mixture of these two herbicides, was evaluated at microscopic and physiological levels.
\end{abstract}

RESULTS: Plants of the two clones showed symptoms of phytotoxicity caused by herbicide drift. However, net $\mathrm{CO}_{2}$ assimilation rate, height and shoot dry matter were lower in CLR-384 than in CLR-383. At the ultrastructure level, the leaves of both clones exposed to the herbicides showed thylakoid disorganization and accumulation of starch grains in the chloroplasts. Only plants of CLR-384 were infected by A. psidii, but when exposed to herbicide drift, rust severity was lower than in control plants. Six days after inoculation (dai), plants of this clone exposed to the herbicides had smaller uredinia than control plants. At 12 dai, non-herbicide treated plants showed normal uredinia, containing abundant urediniospores. By contrast, plants exposed to the herbicides were less colonized by the fungus, and the uredinia were smaller with reduced production of urediniospores, which were sometimes not even detected.

CONCLUSION: Glyphosate and carfentrazone-ethyl herbicide drift reduce infection and uredinial formation of $A$. psidii and to some extent induce basal resistance in a susceptible clone of $E$. grandis.

(c) 2018 Society of Chemical Industry

Supporting information may be found in the online version of this article.

Keywords: fungal infection; myrtle rust; photosynthesis; transmission electron microscopy

\section{INTRODUCTION}

Glyphosate is the most successful herbicide used for weed control in the world. ${ }^{1}$ In Brazil, it is the most used post-emergent herbicide on eucalyptus plantations. However, in areas with frequent applications of glyphosate, some weed species such as Conyza sp. ${ }^{2-4}$ and Commelina sp..$^{5,6}$ have evolved resistance and tolerance to the herbicide molecule, mainly due to the selection pressure. ${ }^{7}$ Carfentrazone-ethyl is an alternative herbicide to control glyphosate-resistant weeds, and has been used alone or in combination with glyphosate..$^{8,9}$

Glyphosate and carfentrazone-ethyl are phytotoxic to eucalyptus, so applications should be conducted appropriately, avoiding direct contact between the herbicide and the crop. Despite this caution, during application, herbicide drift may reach eucalyptus plants and induce leaf chlorosis, necrosis and wilt. ${ }^{10}$ Recently it was found that glyphosate drift reduces rust severity (Austropuccinia psidii) on eucalyptus. ${ }^{11}$ Other studies have also reported that several herbicides with the same mode of action (inhibition of protoporphyrinogen oxidase, PPO) as carfentrazone-ethyl may cause changes in plant metabolism related to plant defense mechanisms against pathogen infection, ${ }^{12-15}$ and affect the severity of fungal diseases in crops. ${ }^{16,17}$

The critical period of weed competition on eucalyptus is $\sim 3.5$ months after planting, ${ }^{18}$ but successive application of herbicides for weed management is commonly performed for up to 2 years. Eucalyptus rust affects mainly young shoots and coppice, ${ }^{19}$ and may occur on plants of susceptible genotypes at 0.5 and 3.0 m height. ${ }^{20}$ Thus, eucalyptus plant stage favorable for

\footnotetext{
* Correspondence to: A Alfenas, Department of Plant Pathology, Universidade Federal de Viçosa, Viçosa, Minas Gerais State, Brazil.E-mail: aalfenas@ufv.br

a Department of Plant Pathology, Universidade Federal de Viçosa, Brazil

b Universidade Federal de Minas Gerais - Campus Regional Montes Claros, Montes Claros, Brazil

c Department of Plant Pathology, Escola Superior de Agricultura 'Luiz de
} Queiroz' - Universidade de São Paulo, Piracicaba, Brazil

d Department of Botany, Universidade Federal do Paraná, Curitiba, Brazil 
rust development is the same period for herbicide application for weed management.

Although glyphosate drift reduces the severity of eucalyptus rust, ${ }^{11}$ we do not know the response of eucalyptus exposed to carfentrazone-ethyl, or a mixture of glyphosate and carfentrazone-ethyl, or the effects of drift of these herbicides on uredinial formation of eucalyptus rust. Therefore, we studied the interaction at the anatomical, ultrastructural and physiological levels of $A$. psidii infection in two Eucalyptus grandis clones, exposed to drift-level doses of these two herbicides alone and in a mixture.

\section{MATERIAL AND METHODS}

\subsection{Plant material and experimental design}

Two assays were carried out between February and April 2015. Rooted cuttings of the first assay were re-conducted for the second assay, and the same methodology was used in both experiments. Cuttings of a resistant (CLR-383) and a susceptible (CLR-384) clone of Eucalyptus grandis to A. psidii were employed. ${ }^{21}$ At 60 days of age, the cuttings were transplanted into $2 \mathrm{~L}$ pots containing MecPlant ${ }^{\circledR}$ substrate enriched with $26 \mathrm{~g}$ of super simple phosphate and $12 \mathrm{~g}$ of Osmocote ${ }^{\circledR}$ (NPK, 19-6-10). During transplanting, each plant per pot received $100 \mathrm{~mL}$ of a mono-ammonium phosphate solution ( $\mathrm{P}$ and $\mathrm{N}$ at $52 \%$ and $12 \%$, respectively; Vale Fertilizantes S.A., Uberaba, MG, Brazil). Plants were kept in a greenhouse with an average temperature of $\sim 25^{\circ} \mathrm{C}$ and natural light $(\sim 12: 12 \mathrm{~h}$ photoperiod) and received the first herbicide drift treatment at 30 days after transplanting.

To simulate field conditions, after finishing the first assay, branches that received the first application of the herbicides were pruned, and rust-infected leaves were removed. After pruning, each plant received $100 \mathrm{~mL}$ of Biofert Universal ${ }^{\circledR}$ fertilizer solution (N, P, K, S, Mg, Cl, Zn, Fe, Mn, Cu, B, Co and Mo at 70.2, 46.8, 46.8, 11.7, 5.85, 3.51, 1.17, 1.17, 0.59, 0.59, 0.23, 0.23 and $0.12 \mathrm{~g} \mathrm{~L}^{-1}$ respectively; Biofert, Contagem, MG, Brazil) diluted in water (1:100). Plants remained in the greenhouse for 20 days and because new shoots did not show any symptoms of herbicide phytotoxicity, the second assay was started.

In both assays, a randomized block experimental design was used with 10 replicates in a factorial scheme $(2 \times 4$, two clones and four herbicide drift-level doses including the control). Each experimental block consisted of a plastic pot containing a eucalyptus plant.

\subsection{Herbicide application}

We tested $3 \mathrm{~g}$ a.i. ha ${ }^{-1}$ carfentrazone-ethyl, $86.4 \mathrm{~g}$ a.i. ha-1 glyphosate and a mixture $\left(3 \mathrm{~g}\right.$ a.i. ha $^{-1}$ carfentrazone-ethyl + $86.4 \mathrm{~g}$ a.i. ha ${ }^{-1}$ glyphosate), corresponding to $6 \%$ of the manufacturer's recommended dose of each herbicide. ${ }^{11}$ Plants sprayed with water served as the control.

In the first assay, the application was performed in February at 30 days after transplanting when plants were $a \sim 50 \mathrm{~cm}$ tall. In the second assay, the application was performed in April (20 days after the end of the first assay). Both applications simulated drift in the lower third of the plants, by utilizing a $\mathrm{CO}_{2}$-pressurized pulverizer backpack equipped with a bar containing two nozzles (model TT 110.02 ), which were calibrated to apply $150 \mathrm{~L} \mathrm{ha}^{-1}$ of herbicide solution.

To avoid contact between the product and other parts of the plant, the top of the canopy was protected with a plastic bag at the time of application, leaving only the lower portion of the plant (approximately three lower branches) exposed to the herbicide.

\subsection{Plant inoculation with Austropuccinia psidii}

In both assays, inoculation was performed 2 days after herbicide application (daa). ${ }^{11}$ The UFV-2 isolate of $A$. psidii (race 1) obtained from E. grandis plants ${ }^{22}$ and multiplied in plants of Sygyzium jambos was used. An inoculum suspension $\left(2 \times 10^{4}\right.$ urediniospores $\mathrm{mL}^{-1}$ ) was homogenously sprayed on both sides of the leaf blade of plants, using a De Vilbiss ${ }^{\circledR}$ atomizer \#15, attached to an electric compressor. To evaluate the efficiency of the inoculation, three $S$. jambos plants were randomly distributed among the eucalyptus plants. After inoculation, plants were incubated in a mist irrigation chamber, in the dark. After $24 \mathrm{~h}$ of incubation, plants were maintained in a growth chamber at $22^{\circ} \mathrm{C}$, with a $12 \mathrm{~h}$ photoperiod and a light intensity of $130 \mu \mathrm{mol}$ photons $\mathrm{m}^{-2} \mathrm{~s}^{-1},{ }^{23}$ until evaluation of rust severity.

\subsection{Response of two clones of eucalyptus to the herbicides}

The sensitivity of the two eucalyptus clones was evaluated at 23 daa, through of the net $\mathrm{CO}_{2}$ assimilation rate $(A)$, plant height and shoot dry matter. The parameter $A$ was determined using a portable open-flow gas exchange system (LI-6400XT, LI-COR). Three measurements were performed on of the fully expanded leaf of the apical part of the plant (protected from the spray), in each plant for each treatment. The measurements were performed from 09:00 to 10:30 am (solar time) - during which $A$ was at its maximum, under artificial photosynthetically active radiation (PAR); i.e. $1000 \mu \mathrm{mol}$ photons $\mathrm{m}^{-2} \mathrm{~s}^{-1}$ at the leaf level and $400 \mu \mathrm{mol}$ $\mathrm{CO}_{2} \mathrm{~mol}^{-1}$. All measurements were performed at $23^{\circ} \mathrm{C}$, the vapor pressure deficit was maintained at $\sim 1.0 \mathrm{kPa}$ and the amount of blue light was set to $10 \%$ PAR to optimize stomatal aperture.

At the end of assay 2, plant height (from the substrate base to the apex) was determined. To determine shoot dry matter, plants were collected near the substrate and stored in paper bags, followed by oven drying with forced ventilation at $65^{\circ} \mathrm{C}$. The paper bags were weighed daily for 5 days until they reached a constant weight.

\subsection{Disease evaluations}

Rust severity was evaluated at 21 days after inoculation (dai) according to the diagrammatic scale. ${ }^{24}$ The data obtained were used to calculate the McKinney Index (MI). ${ }^{25}$ In each plant, three branches were marked, and two leaves were chosen from each branch.

The two leaves selected from each branch were collected and photographed at a distance of $10 \mathrm{~cm}$. Image Pro-Plus v. 4.5 software to determine the infected leaf area (ILA). After photographing, two disks of each sheet were removed using a $6 \mathrm{~mm}$ diameter punch and placed in a $1.5 \mathrm{~mL}$ microcentrifuge tube containing distilled water and Tween-20. After homogenization with a magnetic stirrer for $1 \mathrm{~min}$, two samples of the obtained suspension were placed in a Neubauer camera for urediniospore quantification (UQ).

\subsection{Sample preparation for light, scanning and transmission microscopic analyses}

Leaf samples taken from the apical part of each plant were collected at 6, 12 and 21 dai, and fixed in Karnovsky's solution. ${ }^{26}$ For better penetration of the fixative solution, samples were desiccated under vacuum for $20 \mathrm{~min}$. This last step was performed five times. 
Table 1. Effects of the drift of glyphosate $(G)$, carfentrazone-ethyl $(C E)$ and a mixture of both herbicides $(\mathrm{G}+\mathrm{CE})$ on net $\mathrm{CO}_{2}$ assimilation rate $(A)$, plant height and shoot dry matter of Eucalyptus grandis plants of CLR-383 and CLR-384 clones, at 23 days after application

\begin{tabular}{|c|c|c|c|c|c|c|}
\hline \multirow[b]{2}{*}{ Treatments } & \multicolumn{2}{|c|}{$A\left(\mu \mathrm{mol} \mathrm{m}{ }^{-2} \mathrm{~s}^{-1}\right)$} & \multicolumn{2}{|c|}{ Plant height $(\mathrm{cm})$} & \multicolumn{2}{|c|}{ Shoot dry matter (g/plant) } \\
\hline & CLR-383 & CLR-384 & CLR-383 & CLR-384 & CLR-383 & CLR-384 \\
\hline Control & $14.5 \pm 0.5 \mathrm{Aa}$ & $13.2 \pm 0.6 \mathrm{Aa}$ & $71.8 \pm 1.1 \mathrm{Aa}$ & $69.8 \pm 0.8 \mathrm{Aa}$ & $30.3 \pm 0.9 \mathrm{Aa}$ & $27.7 \pm 0.7 \mathrm{Aa}$ \\
\hline G & $9.9 \pm 0.7 \mathrm{Ab}$ & $9.6 \pm 0.5 \mathrm{Ab}$ & $55.4 \pm 0.8 \mathrm{Ab}$ & $58.5 \pm 1.0 \mathrm{Ab}$ & $23.4 \pm 0.8 \mathrm{Ab}$ & $23.1 \pm 0.5 \mathrm{Ab}$ \\
\hline CE & $12.8 \pm 0.5 \mathrm{Aa}$ & $6.8 \pm 0.4 \mathrm{BC}$ & $68.3 \pm 1.0 \mathrm{Aa}$ & $47.9 \pm 1.5 \mathrm{BC}$ & $28.5 \pm 0.9 \mathrm{Aa}$ & $19.7 \pm 0.5 \mathrm{BC}$ \\
\hline $\mathrm{G}+\mathrm{CE}$ & $9.4 \pm 0.8 \mathrm{Ab}$ & $6.5 \pm 0.7 \mathrm{BC}$ & $52.5 \pm 0.7 \mathrm{Ab}$ & $45.1 \pm 0.7 \mathrm{BC}$ & $22.7 \pm 0.6 \mathrm{Ab}$ & $19.3 \pm 0.6 \mathrm{BC}$ \\
\hline
\end{tabular}

Means ( \pm SEM) followed by the same capital letters in the columns and by the same lowercase letters in the rows did not differ significantly $(P \leq 0.05)$ by Duncan's test.

For light microscopy, samples were dehydrated in an increasing ethanol series $(30 \%, 50 \%, 70 \%, 90 \%$ and $100 \%$; the last wash was repeated three times) and polymerized in acrylic resin-type methacrylate. Cross-sections ( $7 \mu \mathrm{m}$ thickness) were obtained using a manual rotary microtome (Leica RM2155), stained in a toluidine blue solution and mounted on a microscope slide containing Entellan ${ }^{\circledR}$ mounting medium. The samples were observed in a light microscope (Zeiss Axioskop 2), containing a digital camera (MRC3) coupled.

For scanning electron microscopy (SEM), samples were post-fixed in $1 \%$ osmium tetroxide, dehydrated in an acetone series (30\%, 50\%, 70\%, 90\% and 100\%; the last wash was repeated three times) and dried to the critical point (Balzers CPD 030). After assembly in stubs using double-sided carbon tape, samples were metalized with gold (model Balzers SCD 050). Afterward, the material was analyzed by a scanning electron microscope (Zeiss LEO 435-VP) to obtain the electromicrographs.

For transmission electron microscopy (TEM), samples were taken from the Karnovsky fixative, washed three times ( $10 \mathrm{~min}$ each) in $0.05 \mathrm{M}$ sodium cacodylate buffer and post-fixed in $1 \%$ osmium tetroxide for $1 \mathrm{~h}$. Subsequently, samples were treated with $0.5 \%$ uranyl acetate (overnight) and dehydrated in acetone (30\%, 50\%, $70 \%, 90 \%$ and $100 \%$; the last wash was repeated three times). For pre-infiltration and infiltration, samples were treated with a solution of $100 \%$ acetone + Spurr resin $(1: 1, v / v)$ for $6 \mathrm{~h}$ and in Spurr resin for $12 \mathrm{~h}$, respectively. The samples were then polymerized on Spurr resin at $70^{\circ} \mathrm{C}$ for 3 days. After obtaining the blocks, ultrathin sections $(70 \mathrm{~nm})$ were obtained in an ultramicrotome (Leica UC6), using glass razors. The cuts were arranged in copper grids (300 mesh) and contrasted with $2 \%$ uranyl acetate and $1 \%$ lead citrate. ${ }^{27}$ The grids were observed under a transmission electron microscope (JEOL JEM 1100, Akishima, Tokyo, Japan).

\subsection{Data analysis}

The data obtained from the two tests as the net $\mathrm{CO}_{2}$ assimilation rate $(A)$ and the variables $\mathrm{MI}$, ILA and UQ were combined due to the homogeneity of variances between the assays. ${ }^{28}$ The data of $A, \mathrm{MI}$ ILA, UQ, plant height and shoot dry matter were submitted to analysis of variance (ANOVA), and the means were compared by Duncan's test $(P \leq 0.05)$. The Pearson correlation of parameter $A$ with the variables plant height, shoot dry matter, MI, ILA and UQ.

\section{RESULTS}

\subsection{The sensitivity of two clones of eucalyptus to the herbicides}

There was significant clone-herbicide interaction for all variables studied. At 23 daa, plants of clone CLR-384, exposed to all herbicide treatments displayed significantly lower net $\mathrm{CO}_{2}$ assimilation rate $(A)$ and plant growth (height and shoot dry matter) compared with control plants (Table 1). However, CLR-383 was affected only by glyphosate drift-level doses and the mixture of the two herbicides, with reductions of $32 \%$ and $36 \%$ in $A$, of $23 \%$ and $27 \%$ in plant height and of $23 \%$ and $25 \%$ in shoot dry matter, compared with control plants (Table 1).

Plants of both clones showed typical phytotoxicity symptoms due to drift doses of the herbicides. Leaves from the basal part of the plants, directly exposed to carfentrazone-ethyl drift, had brown necrotic spots at 1 daa (Fig. S1). Chlorosis on apical leaves protected from the herbicide application began at 10 daa, except for plants of CLR-383 exposed to the drift-level carfentrazone-ethyl dose (Fig. S2). By contrast to CLR 383, at 23 daa, the basal and apical parts of all plants of clone CLR 384 exposed to the drift-level carfentrazone-ethyl dose had chlorosis on the leaf blade (Fig. S3).

\subsection{Disease evaluation}

On plants of CLR-384, the uredinia dried out when exposed to herbicide drift (Fig. 1b,d), especially to carfentrazone-ethyl or a mixture of glyphosate + carfentrazone-ethyl (Fig. 1c,d), compared with control (Fig. 1a). However, for CLR-383, no uredinia were formed regardless of the treatment (Fig. 1e-h). At 21 dai plants of clone CLR-384 showed less rust infection when exposed to the herbicides glyphosate, carfentrazone-ethyl and their mixture (Fig. 2).

\subsection{Microscopic observations}

Chloroplasts of non-herbicide treated plants of both clones had well-organized thylakoids in grana and without starch grains accumulation (Figs. 3a,d and 4a,b). However, plants of both clones exposed to all herbicide treatments had chlorotic leaves, and the thylakoids were disorganized (Fig. 3b). A large number of peroxisomes were observed in leaf cells of CLR-384 clone plants exposed to carfentrazone-ethyl drift (Fig. 3c). These plants also had an accumulation of starch grains in the chloroplasts when exposed to all three herbicide treatments (Figs. 4c,d,e,g,h), except for the plants of the CLR-383 clone exposed to carfentrazone-ethyl drift (Fig. 4f).

At 6 dai, inoculated and non-herbicide treated plants (control) of CLR-384 showed normal uredinial formation (Fig. 5a,b). However, in herbicide-treated plants, especially those treated with glyphosate + carfentrazone-ethyl, there was almost no epidermis elevation and very few, and small uredinia were formed (Fig. $5 c-h$ ). Intense cell division was also observed in cell layers at the infection site of plants exposed to herbicides (Fig. 5c,e,g).

At 12 dai, the uredinia were completely formed, causing rupture of the cuticle and consequent release of the urediniospores 

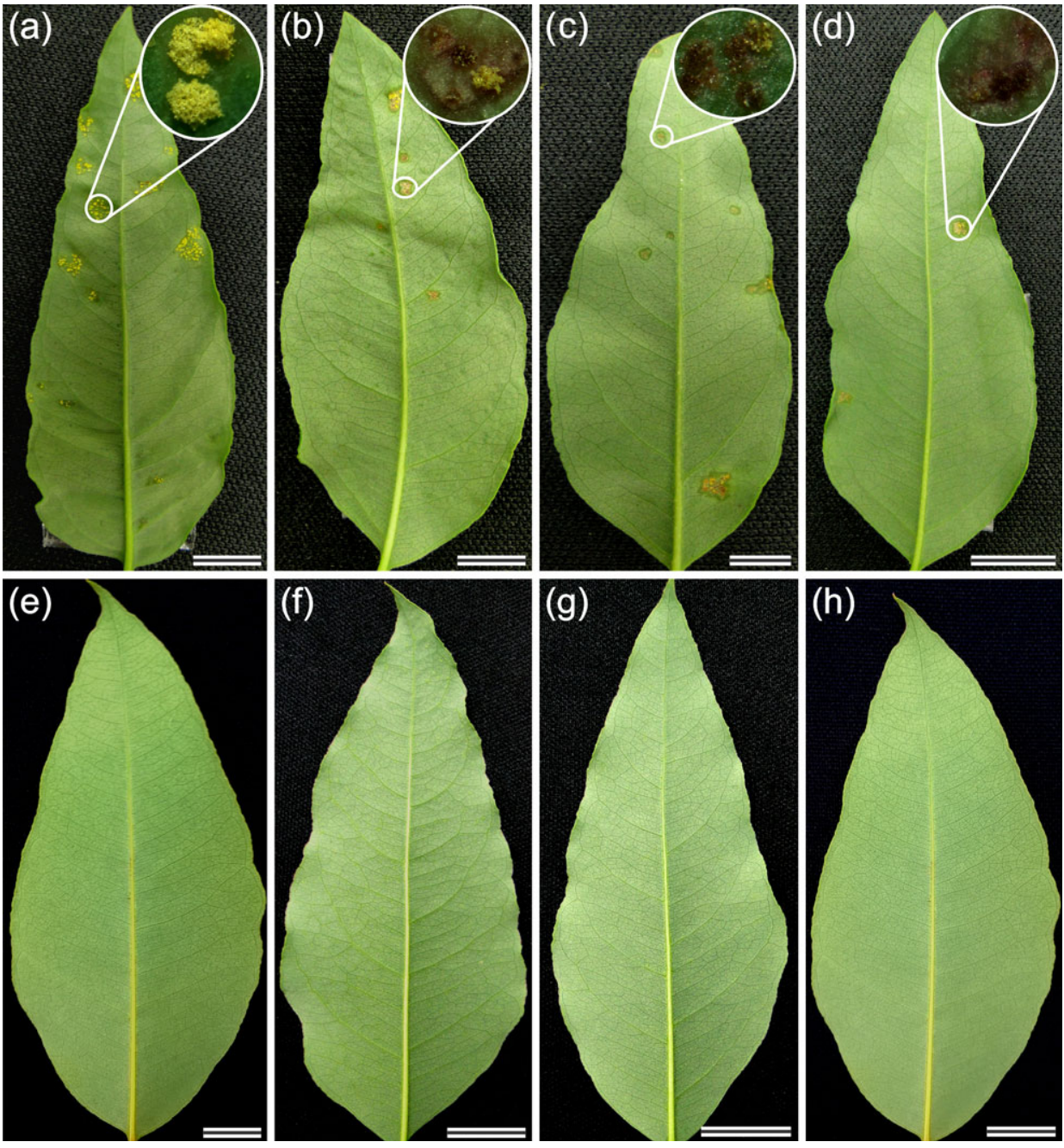

Figure 1. Uredinial formation of Austropuccinia psidii in the abaxial face of leaves of Eucalyptus grandis plants of clones CLR-384 (a-d) and CLR-383 $(e-h)$ exposed to water (control treatment) $(a, e)$, glyphosate $(b, f)$, carfentrazone-ethyl $(c, g)$ and a mixture of glyphosate + carfentrazone-ethyl $(d, h)$ at 21 days after inoculation. (a) Well-developed uredinia with an abundant production of urediniospores. (b, d) Uredinia with malformation and with reduced production of urediniospores. $(\mathrm{e}-\mathrm{h})$ Absence of uredinia. Scale bars $=1 \mathrm{~cm}$.

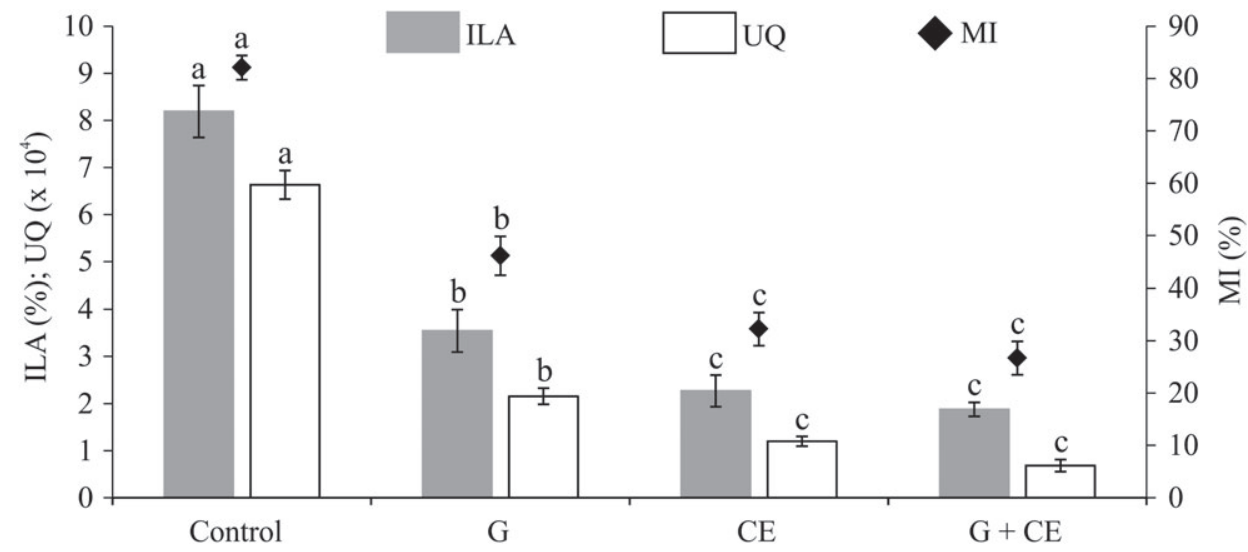

Figure 2. Infected leaf area (ILA), urediniospore number (UQ) and McKinney index (MI) on Eucalyptus grandis plants of clone CLR-384 sprayed with water (control), glyphosate (G), carfentrazone-ethyl (CE) and a mixture of glyphosate + carfentrazone-ethyl (G + CE) at 21 days after inoculation with Austropuccinia psidii. For each variable, means followed by the same letters did not differ significantly $(P \leq 0.05)$ by Duncan's test. Bars $=$ mean SE. 

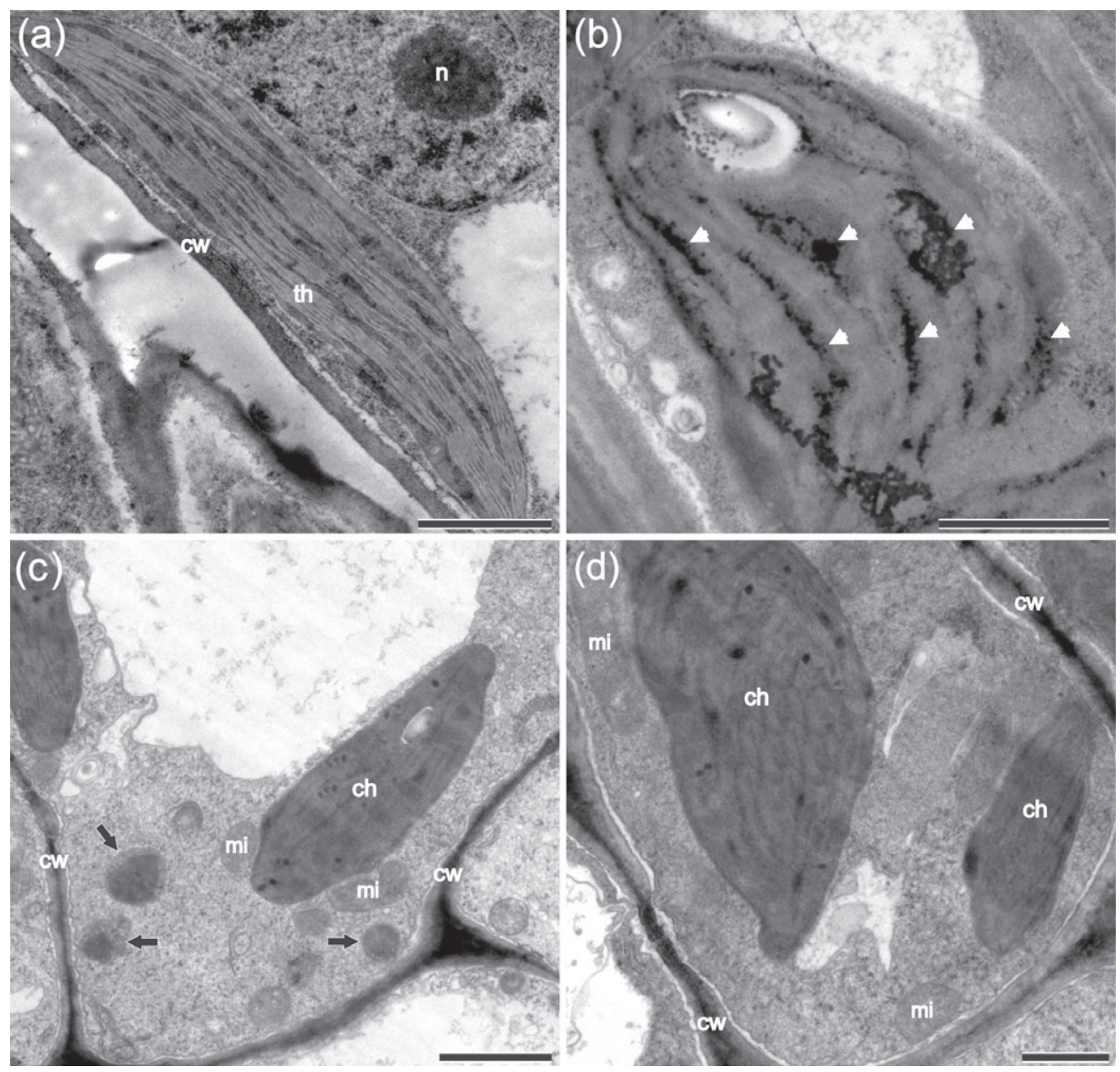

Figure 3. Transmission electron micrographs of transverse sections of Eucalyptus grandis leaves of clones CLR-383 (a, b) and CLR-384 (c, d) sprayed with water (a, d), glyphosate (b) and carfentrazone-ethyl (c) at 14 days after spraying. (a) Chloroplast with normal appearance and thylakoids organized in grana. (b) Chloroplast with disorganized thylakoids (arrowhead). (c) Presence of peroxisomes (arrows). (d) Absence of peroxisomes on leaf tissue of plants exposed to water. $\mathrm{cw}$, cell wall; $\mathrm{mi}$, mitochondria; $\mathrm{n}$, nucleus; th, thylakoids. Scale bars $=1 \mu \mathrm{m}$.

(Fig. 6). In plants exposed to herbicide drift, leaf tissue was less colonized by the fungus, compared with control plants in which uredinia were large and showed abundant urediniospore production (Fig. 6a,b). In plants previously exposed to herbicides, the uredinia were smaller with reduced (Fig. 6c,f) or undetected (Fig. 6g,h) urediniospore production. In addition, cells of the palisade parenchyma showed altered morphology at the infection site (Fig. 6c,e). In plants exposed to the glyphosate + carfentrazone-ethyl mixture, cells were completely degenerate (Fig. 6g).

In transverse sections of leaves exposed to herbicide drift, compartmentalization tissue was formed (Fig. 6c,e,g). In plants sprayed with glyphosate and carfentrazone-ethyl drift-level doses in isolation, the tissue had two layers (Fig. 6c,e), whereas in plants exposed to a drift-level dose of the glyphosate + carfentrazone-ethyl mixture, the compartmentalization tissue was stratified into three or more layers (Fig. 6g).

\subsection{Pearson correlation}

There was a significant $(P \leq 0.01)$ and positive correlation between net $\mathrm{CO}_{2}$ assimilation rate, $A$, and plant height $(r=0.92)$ and shoot dry matter $(r=0.97)$ for the CLR-383 clone $(r=0.96$ and 0.98 , respectively, for CLR-384 clone). For the CLR-384 clone, parameter
A was also significantly $(P \leq 0.01)$ correlated with MI, ILA and UQ ( $r=0.95,0.94$ and 0.93 , respectively).

\section{DISCUSSION}

Although there has been a report of reduced rust infection in eucalyptus by glyphosate drift, ${ }^{11}$ the current study confirms previous findings and demonstrates microscopic and physiological responses in $E$. grandis treated with glyphosate, carfentrazone-ethyl and a mixture of these two active ingredients.

The two clones tested differed in herbicide sensitivity, expressed by the net $\mathrm{CO}_{2}$ assimilation rate $(A)$, plant height and shoot dry matter. Differences in tolerance to glyphosate have been reported in Eucalyptus genotypes. ${ }^{10}$ The activity of glyphosate varies with its absorption and translocation rate. ${ }^{29}$ Other authors working with fomesafen, a herbicide with the same mode of action (inhibition of PPO) as carfentrazone-ethyl, also observed a reduction in the dry mass of shoots from two hybrids of $E$. urophylla $\times$ E. grandis. $^{30}$

The tested herbicides may have affected $\mathrm{CO}_{2}$ assimilation through their effect on disorganization of the thylakoid membranes. Also, glyphosate indirectly affects photosynthesis by inhibiting the biosynthesis of carotenoids, chlorophylls, fatty acids 

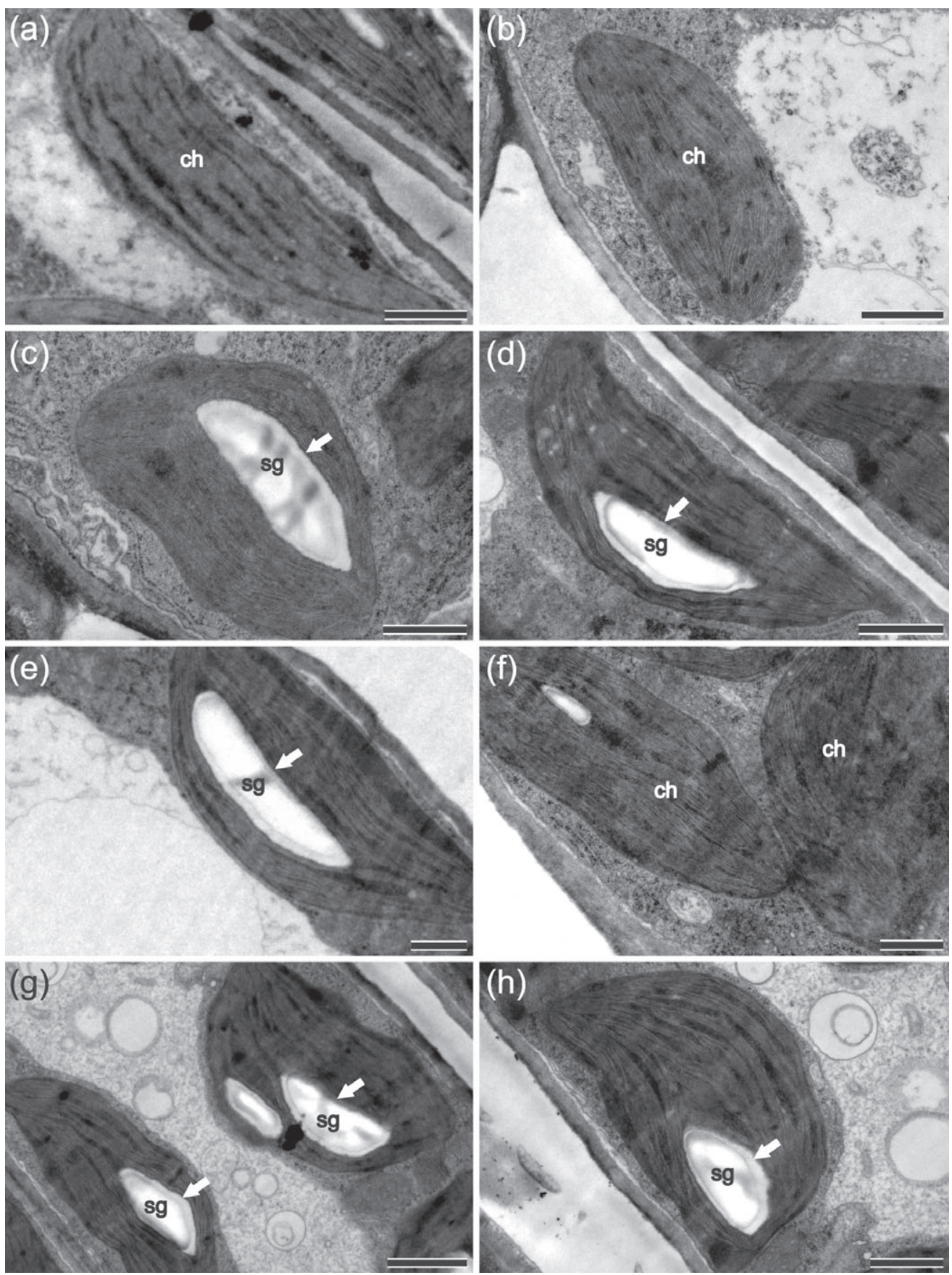

Figure 4. Transmission electron micrographs of transverse sections of Eucalyptus grandis leaves of clones CLR-384 (a, c, e, g) and CLR-383 (b, d, f, h) exposed to water $(\mathrm{a}, \mathrm{b})$ and to the herbicides glyphosate $(\mathrm{c}, \mathrm{d})$, carfentrazone-ethyl $(\mathrm{e}, \mathrm{f})$ and a mixture of glyphosate $+\mathrm{carfentrazone-ethyl}(\mathrm{g}, \mathrm{h})$ at 23 days after spraying. ( $(a, b, f)$ Starch grains were not evident. (c-e, g, h) Presence of very well formed starch grains (white arrows). ch, chloroplast; sg, starch grains. Scale bars $=1 \mu \mathrm{m}$.

and amino acids, ${ }^{31}$ as well as secondary metabolism products essential for photosynthesis such as quinones. ${ }^{32}$ In the current study, there was a reduction in net $\mathrm{CO}_{2}$ assimilation rate $(A)$ values for plants of the two $E$. grandis clones exposed to glyphosate, as reported for several plant species exposed to this herbicide. ${ }^{33-35}$ Although there are no reports of the effect of carfentrazone-ethyl on photosynthesis in eucalyptus plants, this herbicide inhibits PPO, which is important in chlorophyll biosynthesis. ${ }^{36}$ However, most of its effects are due to oxidative stress caused by accumulation the photosensitizing pigment protoprorphyin IX. ${ }^{37}$
Although the respiration rate was not evaluated in this study, the presence of starch grains in the chloroplasts, associated with reduced growth in plants exposed to herbicide drift, indicates a possible reduction in metabolite processes such as respiration rate in these plants. Plant respiration consists of the oxidation of glucose that yields energy, used by plants in their vital processes. During the day, the glucose consumed in respiration comes from photosynthesis, whereas at night it comes from reserves accumulated during the day, usually in the form of starch grains. ${ }^{38}$ Because starch grains were observed in leaf samples collected at 08:00, this 

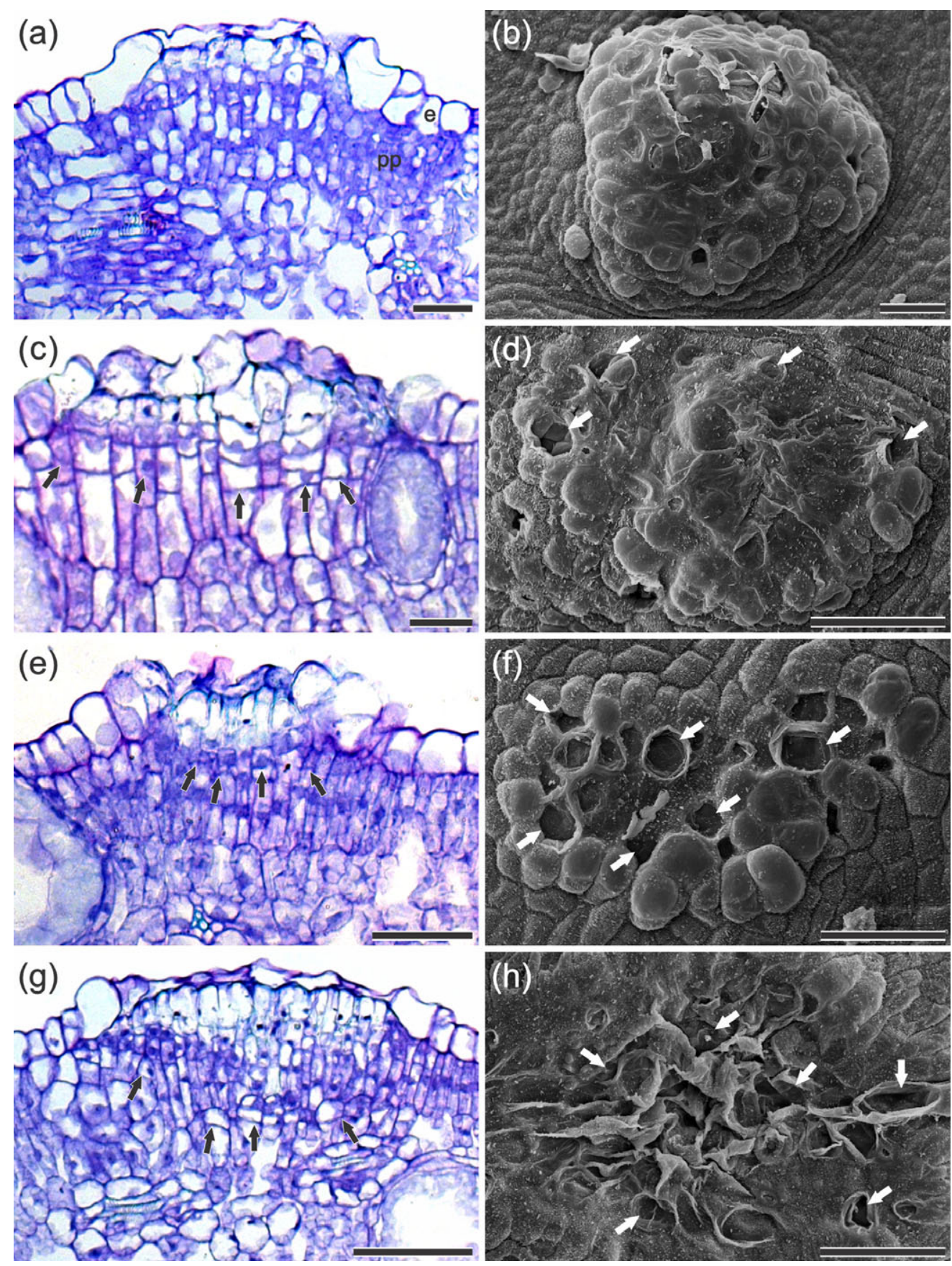

Figure 5. Light micrographs of transverse sections $(a, c, e, g)$ and scanning electron micrographs of the abaxial surface (b, $d, f, h)$ of Eucalyptus grandis leaves of the clone CLR-384 sprayed with water $(a, b)$, glyphosate $(c, d)$, carfentrazone-ethyl $(e, f)$ and a mixture of glyphosate + carfentrazone-ethyl $(g$, h) at 6 days after inoculation with Austropuccinia psidii. (a, b) Well-developed uredinia. (c, e, g) Cell division at the infection site (black arrows). (d, $f$, h) Malformed uredinia with (white arrows). e, epidermis; pp, palisade parenchyma. Scale bars $=50 \mu \mathrm{m}$.

may indicate that starch was not used by the respiratory system in the previous night. Also, a reduction in the respiration rate is common in plants exposed to herbicide drift. ${ }^{39}$

Glyphosate and carfentrazone-ethyl did not break down the rust resistance of CLR-383 clone, controlled by the Ppr-1 locus, ${ }^{21}$ but they increased the basal resistance of the susceptible clone (CLR-384). Several studies report in vitro glyphosate inhibition of spore germination and hyphal growth of various fungal species, ${ }^{40,41}$ including $A$. psidii. ${ }^{11}$ This inhibition may occur in the shikimic acid pathway, which is affected by glyphosate in some fungi. ${ }^{42}$ This molecule has a negative effect on the development of some fungal diseases, mainly rusts. ${ }^{43}$ Previously, studies have shown significant lower rust severity of eucalyptus rust in cuttings of the same clones used in our studies, when these were submitted to glyphosate drift. ${ }^{11}$ Similar results were observed for other pathogens in several crops. In herbicide-resistant transgenic soybeans, spraying with glyphosate reduced the severity of soybean Asian rust (Phakopsora pachyrhizi), ${ }^{44,45}$ powdery mildew (Erysiphe diffusa) and leaf spot (Myrothecium roridum).$^{40}$ In glyphosate-resistant alfalfa cultivation, spraying of this herbicide 

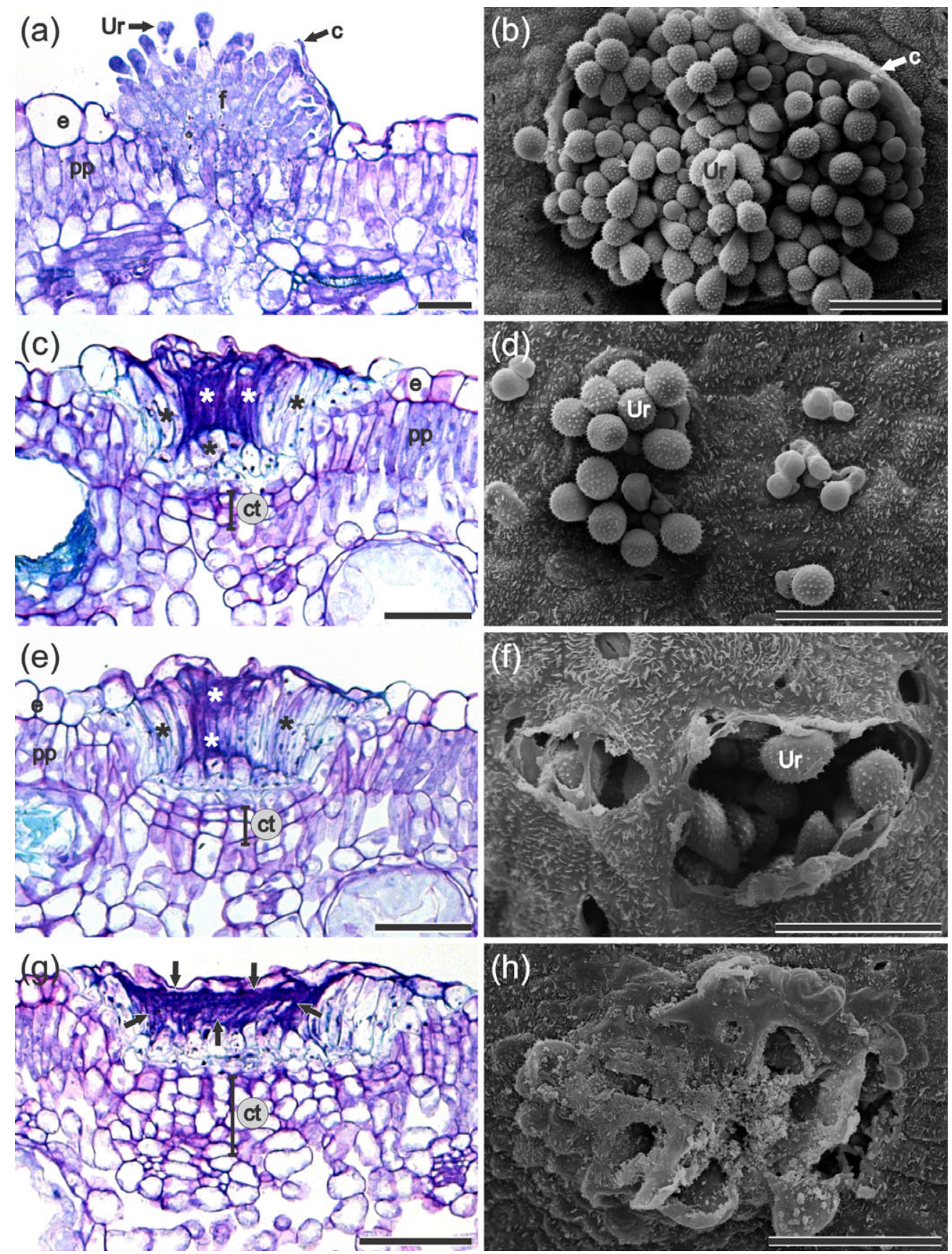

Figure 6. Light micrographs of transverse sections $(a, c, e, g)$ and scanning electron micrographs of the abaxial surface (b, d, $f, h)$ of Eucalyptus grandis leaves of clone CLR-384 sprayed with water $(a, b)$, glyphosate $(c, d)$, carfentrazone-ethyl $(e, f)$ and a mixture of glyphosate + carfentrazone-ethyl $(g$, h) at 12 days after inoculation with Austropuccinia psidii. (a, b) Well-developed uredinia with abundant production of urediniospores; (c, h) malformed uredinia; $(c, e)$ cells of the palisade parenchyma with altered morphology (asterisks); $(d, f)$ reduced production of urediniospores; $(g)$ cells of the palisade parenchyma degenerated (arrows); and (h) uredinia without evident release of urediniospores. c, cuticule; ct, compartmentalization tissue; e, epidermis; f, fungal hyphae; pp, palisade parenchyma; Ur, urediniospores. Scale bars $=50 \mu \mathrm{m}$.

reduced the severity of rust caused by Uromyces striatus. ${ }^{41}$ In glyphosate-resistant wheat, glyphosate application provided both preventive and curative activities on control of stripe (Puccinia striiformis f. sp. tritici) and rust (Puccinia triticina). ${ }^{44,46}$

Although there are no reports of the effect of carfentrazone-ethyl on the severity of fungal diseases, the abundance of peroxisomes observed in leaves of the rust-susceptible clone (CLR-384), exposed to herbicide drift, may be related to a reduction in the severity by the herbicide. Peroxisomes produce peroxidase, a key enzyme in the defense against fungal pathogens. ${ }^{47}$ In addition, studies with other PPO inhibitors reported their induction of pathogen resistance in plants. Soybean plants treated with lactofen and inoculated with Sclerotinia sclerotiorum had lower lesion diameters, due mainly to a high glyceollin content in the leaves. ${ }^{16}$ In glyphosate-resistant soybean, lactofen also increased phytoalexin production, reduced Sclerotinia stem rot lesion diameter and reduced disease severity index. ${ }^{17}$ In several crops, the herbicides acifluorfen and lactofen 
induce the accumulation of some compounds related to plant defense mechanisms against pathogens such as phytoalexins and stress metabolites, ${ }^{12}$ camalexin $^{13}$ and isoflavone. ${ }^{14}$

By inhibiting the synthesis of the 5-enolpyruvyl-shikimate-3phosphatase, glyphosate reduces the synthesis of aromatic amino acids such as tryptophan, phenylalanine and tyrosine. ${ }^{48}$ Such amino acids are essential for fungal mycelial growth. ${ }^{40}$ In additionally, by reducing the net $\mathrm{CO}_{2}$ assimilation rate $(A)$, the action of herbicides such as glyphosate also affects the synthesis of sugars, amino acids and proteins. ${ }^{49}$ Biotrophic pathogens, such as $A$. psidii, depend on living host tissues. ${ }^{19}$ In this study, plants of both eucalyptus clones exposed to a drift-level dose of the herbicides glyphosate and carfentrazone-ethyl had a reduced net $\mathrm{CO}_{2}$ assimilation rate $(A)$. The positive and significant Pearson correlation of the parameter $A$ with plant height, shoot dry matter, MI, ILA and $U Q$, in addition to poor uredinial formation, reinforces the deleterious effect of glyphosate and carfentrazone-ethyl herbicide drift on $A$ values, as well as their indirect influence on development of rust in plants of clone CLR-384 of E. grandis.

The results of this study demonstrate the effects of glyphosate and carfentrazone-ethyl herbicide drift on rust in eucalyptus. Application of these herbicides for weed management is more frequent in the first year after planting ${ }^{18}$ when the plants are more vulnerable to rust infection. ${ }^{19}$ It is emphasized that most plant defense compounds against pathogen infection come from secondary metabolism, which may be directly or indirectly affected by the use of herbicides. In this context, there is a need for further studies to determine the effect of herbicides on infection by other important pathogens in eucalyptus plantations for a sustainable integrated phytosanitary management.

\section{CONCLUSION}

The glyphosate and carfentrazone-ethyl herbicide drift does not break down rust resistance, but increases the basal resistance of susceptible eucalyptus clones, as well as inhibiting the uredinial formation of $A$. psidii during infection on eucalyptus leaves.

\section{ACKNOWLEDGEMENTS}

The authors thanks the 'Conselho Nacional de Desenvolvimento Científico e Tecnológico' (CNPq) for the fellowship granted to the second, third and sixth authors; the 'Coordenação de Aperfeiçoamento de Pessoal de Nível Superior' (CAPES) for the fellowship granted to first the author; the 'Núcleo de Apoio à Pesquisa em Microscopia Eletrônica Aplicada à Pesquisa Agropecuária of the Escola Superior de Agricultura Luiz de Queiroz' for the support in the microscopic analysis. This study was supported by grants from the 'Fundação de Amparo à Pesquisa do Estado de Minas Gerais' (FAPEMIG) awarded to Prof. L. D. Tuffi-Santos.

\section{SUPPORTING INFORMATION}

Supporting information may be found in the online version of this article.

\section{REFERENCES}

1 Duke SO, Glyphosate: the world's most successful herbicide under intense scientific scrutiny. Pest Manag Sci 74:1025-1026 (2018).

2 Lamego FP and Vidal RA, Resistance to glyphosate in Conyza bonariensis and Conyza canadensis biotypes in Rio Grande do Sul. Braz Planta Daninha 26:467-471 (2008).
3 Okada M, Hanson BD, Hembree KJ, Peng Y, Shrestha A, Stewart CN et al., Evolution and spread of glyphosate resistance in Conyza bonariensis in California and a comparison with closely related Conyza canadensis. Weed Res 55:173-184 (2015).

4 Kleinman Z and Rubin B, Non-target-site glyphosate resistance in Conyza bonariensis is based on modified subcellular distribution of the herbicide. Pest Manag Sci 73:246-253 (2017).

5 Santos IC, Silva AA, Ferreira FA, Miranda GV and Pinheiro RAN, Efficiency of glyphosate in the control of Commelina benghalensis and Commelina diffusa. Planta Daninha 19:135-143 (2001).

6 Ulloa SM and Owen MDK, Response of Asiatic dayflower (Commelina communis) to glyphosate and alternatives in soybean. Weed Sci 57:74-80 (2009).

7 Heap I and Duke SO, Overview of glyphosate-resistant weeds worldwide. Pest Manag Sci 74:1040-1049 (2018).

8 Werlang RC and Silva AA, Glyphosate-carfentrazone-ethyl interaction. Planta Daninha 20:93-102 (2002).

9 Moreira MS, Melo MSC, Carvalho SJP, Nicolai M and Crhistoffoleti PJ, Alternative herbicides to control glyphosate-resistant biotypes of Conyza bonariensis and C. canadensis. Planta Daninha 28:167-175 (2010).

10 Tuffi-Santos LD, larema L, Thadeo M, Ferreira FA and Meira RMSA, Characteristics of eucalypt leaf epidermis and its role in glyphosate tolerance. Planta Daninha 24:513-520 (2006).

11 Tuffi-Santos LD, Graça RN, Alfenas AC, Ferreira FA, Melo CA and Machado MS, Glyphosate reduces urediniospore development and Puccinia psidii disease severity on Eucalyptus grandis. Pest Manag Sci 67:876-880 (2011)

12 Komives T and Casida JE, Acifluorfen increases the leaf content of phytoalexins and stress metabolites in several crops. J Agric Food Chem 31:751-755 (1983).

13 Zhao J, Williams CC and Last RL, Induction of Arabidopsis tryptophan pathway enzymes and camalexin by amino acid starvation, oxidative stress, and an abiotic elicitor. Plant Cell 10:359-370 (1998).

14 Landini S, Graham MY and Graham TL, Lactofen induces isoflavone accumulation and glyceollin elicitation competency in soybean. Phytochemistry 62:865-874 (2003).

15 Langaro AC, Agostinetto D, Oliveira C, Silva JDG and Bruno MS, Biochemical and physiological changes in rice plants due to the application of herbicides. Planta Daninha 34:277-290 (2016).

16 Dann EK, Diers BW and Hammerschmidt R, Suppression of Sclerotinia stem rot of soybean by lactofen herbicide treatment. Phytopathology 89:598-602 (1999).

17 Nelson KA, Renner KA and Hammerschmidt R, Cultivar and herbicide selection affects soybean development and the incidence of Sclerotinia stem rot. Agron J 94:1270-1281 (2002).

18 Tarouco CP, Agostinetto D, Panozzo LE, dos, Santos LS, Vignolo GK and de O Ramos LO, Weed interference periods on in the initial growth of eucalyptus. Pesq Agropec Bras 44:1131-1137 (2009).

19 Alfenas AC, Zauza EAV, Mafia RG and Assis TF, Clonagem e doenças do eucalipo. Editora UFV, Viçosa, p. 500 (2009).

20 Zauza EAV, Couto MMF, Lana VM, Maffia LA and Alfenas AC, Vertical spread of Puccinia psidii urediniospores and development of eucalyptus rust at different heights. Australas Plant Pathol 39:141-145 (2010).

21 Junghans DT, Alfenas AC, Brommonschenkel SH, Oda S, Mello EJ and Grattapaglia D, Resistance to rust (Puccinia psidii Winter) in Eucalyptus: mode of inheritance and mapping of a major gene with RAPD markers. Theor Appl Genet 108:175-180 (2003).

22 Xavier AA, da Silva AC, da Silva Guimarães LM, Matsuoka K, Hodges CS and Alfenas AC, Infection process of Puccinia psidii in Eucalyptus grandis leaves of different ages. Trop Plant Pathol 40:318-325 (2015).

23 Ruiz RAR, Alfenas AC, Ferreira FA and Vale FXR, Influência da temperatura, do tempo de molhamento foliar, fotoperíodo e da intensidade de luz sobre a infecção de Puccinia psidii em eucalipto. Fitopatol Bras 14:55-61 (1989).

24 Junghans DT, Alfenas AC and Maffia LA, Rating scale to eucalypts rust severity evaluation. Fitopatol Bras 28:184-188 (2003).

25 Mckinney $\mathrm{HH}$ and Davis RJ, Influence of soil temperature and moisture on infection of wheat seedlings by Helminthosporium sativum. J Agric Res 31:827-840 (1925).

26 Karnovsky MJ, A formaldehyde-glutaraldehyde fixative of high osmolarity for use in electron microscopy. J Cell Biol 27:137-138 (1965).

27 Reynolds ES, The use of lead citrate at high $\mathrm{pH}$ as an electron-opaque stain in electron microscopy. J Cell Biol 17:208-212 (1963). 
28 Gomes FP and Guimarães RF, Joint analysis of experiments in complete randomised blocks with some common. Biometrics 14:521-526 (1958).

29 McCullough PE, Yu J, Shilling DG and Czarnota MA, Physiological basis for glyphosate tolerance in hard fescue and perennial ryegrass cultivars. Crop Sci 55:2352-2358 (2015).

30 Tiburcio RAS, Ferreira FA, Paes FASV, Melo CAD and Medeiros WN, Growth of eucalyptus clones seedlings submitted to simulated drift of different herbicides. Rev Árvore 36:65-73 (2012).

31 Fedtke $\mathrm{K}$ and Duke S, Herbicides, in Plant Toxicology, ed. by Hock B and Elstner E. New York, NY, Marcel Dekk, p. 648 (2005).

32 Knaggs AR, The biosynthesis of shikimate metabolites. Nat Prod Rep 20:119-136 (2003).

33 Gomes MP, Smedbol E, Chalifour A, Hénault-Ethier L, Labrecque M, Lepage $L$ et al., Alteration of plant physiology by glyphosate and its by-product aminomethylphosphonic acid: an overview. J Exp Bot 65:4691-4703 (2014).

34 Gomes MP, Le Manac'h SG, Maccario S, Labrecque M, Lucotte M and Juneau $P$, Differential effects of glyphosate and aminomethylphosphonic acid (AMPA) on photosynthesis and chlorophyll metabolism in willow plants. Pestic Biochem Physiol 130:65-70 (2016).

35 Radwan DEM and Fayez KA, Photosynthesis, antioxidant status and gas-exchange are altered by glyphosate application in peanut leaves. Photosynthetica 54:307-316 (2016).

36 Kobayashi K, Masuda T, Tajima N, Wada H and Sato N, Molecular phylogeny and intricate evolutionary history of the three isofunctional enzymes involved in the oxidation of protoporphyrinogen IX. Genome Biol Evol 6:2141-2155 (2014).

37 Vítek P, Novotná K, Hodaňová P, Rapantová B and Klem K, Detection of herbicide effects on pigment composition and PSII photochemistry in Helianthus annuus by Raman spectroscopy and chlorophyll a fluorescence. Spectrochim Acta Part A Mol Biomol Spectrosc 170:234-241 (2017).

38 Duffus CM, Metabolism of reserve starch, in Storage Carbohydrates in Vascular Plants, ed. by Lewis DH. Cambridge, MA, Cambridge University Press, p. 284 (1984).
39 Ding W, Reddy KN, Zablotowicz RM, Bellaloui N and Arnold Bruns $\mathrm{H}$, Physiological responses of glyphosate-resistant and glyphosate-sensitive soybean to aminomethylphosphonic acid, a metabolite of glyphosate. Chemosphere 83:593-598 (2011).

40 Rosa DD, Basseto MA, Cavariani C and Furtado EL, Effect of herbicides on phytopathogenic agents. Acta Sci Agron 32:379-383 (2010).

41 Samac DA and Foster-Hartnett D, Effect of glyphosate application on foliar diseases in glyphosate-tolerant alfalfa. Plant Dis 96:1 104-1110 (2012).

42 Richards TA, Dacks JB, Campbell SA, Blanchard JL, Foster PG, McLeod R et al., Evolutionary origins of the eukaryotic shikimate pathway: gene fusions, horizontal gene transfer, and endosymbiotic replacements. Eukaryot Cell 5:1517-1531 (2006).

43 Hammerschmidt R, How glyphosate affects plant disease development: it is more than enhanced susceptibility. Pest Manag Sci 74:1054-1063 (2018).

44 Feng PCC, Baley GJ, Clinton WP, Bunkers GJ, Alibhai MF, Paulitz TC et al., Glyphosate inhibits rust diseases in glyphosate-resistant wheat and soybean. Proc Natl Acad Sci 102:17290-17295 (2005).

45 Feng PC, Clark C, Andrade GC, Balbi MC and Caldwell P, The control of Asian rust by glyphosate in glyphosate-resistant soybeans. Pest Manag Sci 64:353-359 (2008).

46 Anderson JA and Kolmer JA, Rust control in glyphosate tolerant wheat following application of the herbicide glyphosate. Plant Dis 89:1136-1142 (2005).

47 Pereira SC, Rodrigues FA, Carré-Missio V, Oliveira MAG and Zambolim L, Effect of foliar application of silicon on soybean resistance against soybean rust and on the activity of defense enzymes. Trop Plant Pathol 34:164-170 (2009).

48 Jaworski EG, Mode of action of $\mathrm{N}$-phosphonomethylglycine: inhibition of aromatic amino acid biosynthsis. J Agric Food Chem 20:1 195-1198 (1972).

49 Machado AFL, Ferreira LR, Tuffi-Santos LD, Ferreira FA, Viana RG, Machado MS et al., Photosynthetic efficiency and water use in eucalyptus plants sprayed with glyphosate. Planta Daninha 28:319-327 (2010). 